\title{
NOx Emission Analysis in Flue Gas of Coal Fired Thermal Power Station and it's Control Measure
}

\author{
T.P.Meikandaan, M. Hemapriya, V. Vidhya
}

\begin{abstract}
The growth and development of any country is measured by the electricity generation which paves way for industrialization and mechanization. To meet the ever increasing demand, the best way to generate consistent power is setting up of large thermal power plants. India is rich with coal reserves and is very cheap when compared with other fuels, hence coal is used as the primary fuel for power generation in India. Thermal generation using coal accounts for $65 \%$ of the total power produced. Power plants in India uses different qualities of coal, different combustion technologies and operating conditions. Flue Gases emitted from coal fired thermal stations consists of CO2,(Carbon-di-oxide),SOx (Oxides of Sulphur), NOx (Oxides of Nitrogen), PM (Particulate matter) along with carbonaceous material, soot and Fly ash. These gaseous pollutants are considered as environmental burden which ultimately results in smog formation, formation of acid rain, eutrophication and global warming and has to be controlled and regulated to be within the permissible limits as stipulated by MOEF \&CC (Ministry of Environmental Forest and Climate Change). This project describes about the analysis of NOx Emission in Flue Gas of Coal fired thermal stations and the measures to control the NOx emission within the permissible limits for the existing thermal power plants by modifying the combustion technology without affecting the power generation. The primary measure to control NOx emission is achieved by in - combustion control by modifying the conventional burner with the Low Nox Burner combined with Over Fire Air which bring about 45-80\% NOx emission reduction, which is cost effective and could be implemented with minimum down time for installation. The application of Low Nox Burner with Over Fire Air Technology in the existing thermal power plant has reduced the emission of $N O x$ to a considerable extent and to meet the norms within minimum period without affecting the power generation.
\end{abstract}

Key words: Low NOx Burner, Over Fire Air, SCR, SNCR.

\section{INTRODUCTION}

The strategic maneuvers an essential job for improvement of any country and having its significance in by and large GDP development. India is the world's 6th biggest economy and has a quickly developing vitality showcase. India is the world's third biggest maker and third biggest purchaser of power. The power supply in our nation surely can't keep up

Revised Manuscript Received on October 22, 2019.

T.P.Meikandaan, Department of Civil Engineering, Bharath Institute of Higher Education and Research, Selaiyur, Chennai, Tamilnadu.Email: ganga_meik@yahoo.co.in

M. Hemapriya, Department of Civil Engineering, Bharath Institute of Higher Education and Research, Selaiyur, Chennai, Tamilnadu .Email: meihemapriya@gmail.com

V. Vidhya, Department of Civil Engineering, Bharath Institute of Higher Education and Research, Selaiyur, Chennai, Tamilnadu.Email: anna_kalai@yahoo.com the popularity with expanding populace and mechanical advancement. Setting up enormous warm power plants is most likely answer for meet developing

power request, since the land necessity is less, simple to keep up, conservative expense of age and above all steady power age. Copious inventory of coal locally and continued significant expenses for imported flammable gas and oil make coal-terminated age of power progressively appealing financially.

The significant segment of intensity age overall is through coal. India's power area is ruled by petroleum products, and specifically coal, which during 2017-18 created around three fourths of all power. The fundamental favorable position of setting up huge warm power plants, is with the end goal that it produces predictable power and unseasonal. India is significantly reliant on coal for its vitality needs. We have huge assets of high-grade coal in a few states. Unmistakably from the factual state, our coal generation is something like 550-600 million tons per year on a normal. Presently the all out stores according to Ministry of coal in our nation is 301.5 Billion tonnes(includes unproved stores) as per which the coal would effortlessly keep going for significantly more than 400 years. Coal is the fundamental wellspring of vitality in India as it satisfies very nearly 67 percent of the all out business vitality expended in the nation.

\section{A. CLASSIFICATION OF COAL}

Coal, the world's most plentiful fossil fuel often known as 'Black Gold'. is originated from organic matter wood. Due to decomposition of forests and due to heat from below and pressure coal takes centuries to complete. Based on the carbon content present in the coal, they are classified as follows:

\begin{tabular}{|l|l|l|}
\hline Type of coal & $\begin{array}{l}\text { Carbon } \\
\text { Content }\end{array}$ & Calorific Value \\
\hline Anthracite & $80-95 \%$ & Very high \\
\hline Bituminous & $60-80 \%$ & High \\
\hline Lignite & $40-55 \%$ & Medium \\
\hline Peat & $>40 \%$ & Low \\
\hline
\end{tabular}

\section{B. COMPOSITION OF COAL}

Typical compositions and analysis of (mass percentages) of coal include Ultimate Analysis 


$\begin{array}{lll}\text { Carbon } & - & 65-95 \%, \\ \text { Hydrogen } & - & 2-7 \% \\ \text { Oxygen } & - & \text { up to } 25 \% \text { oxygen } \\ \text { Sulphur } & - & 10 \% \text { and } \\ \text { Nitrogen } & - & 1-2 \%\end{array}$

Proximate Analysis

Inorganic mineral matter (ash) - > 50\%. Moisture levels - 2 to $20 \%$, Volatile matter and fixed carbon.:

\section{IMPACT OF NOX ON ENVIRONMENT}

NOx contributes to Acid Rain leading to damage to vegetation and Aquatic Life.

- NOx is affecting Ozone (O3) balance, is a precursor for photochemical smog contributors (Ozone, PAN, HNO3) in troposphere which causes damage of the human respiratory system (lungs).

- NOx can contribute to eutrophication and influences ecosystem by nutrient overload.

- Acidic gases along with airborne particles cause visibility impairment and lower air quality.

\section{EFFECTS OF COMBUSTION OF COAL IN THERMAL POWER PLANTS}

The important factor for good combustion is to prepare the coal before feeding into the boiler. Sizing of coal is one of the key measures to ensure efficient combustion. Proper coal sizing, with specific relevance to the type of firing system, helps towards even burning, reduced ash losses and better combustion efficiency.

The combustion of coal in thermal power stations can lead to emission of flue gases such as $\mathrm{CO} 2, \mathrm{NOx}, \mathrm{SOx}$, and air-borne inorganic particles such as fly ash, carbonaceous material (soot), Suspended Particulate Matter (SPM), and other trace gas species which are hazardous in nature and are a constant threat to the environment, human and other ecosystem.

The most important thing is to strike a balance between the power generation and methods to limit the emissions (particulate matter, nitrogen oxides, sulfur oxides, carbon oxides, etc.). In order to achieve reduction in the emissions it is necessary to apply advanced and efficient technologies and to operate the power plants within the norms stipulated by the ministry of environment, forest and climate change. (MOEF $\& \mathrm{CC})$.

\section{MEASUREMENTS AND DATA COLLECTION}

\section{A. Indian standard method for measurement of nox from stationary sources}

There are two types for Monitoring and measurement of the gaseous pollutants emitted from the power plants namely,

Continuous Emission Monitoring System(CEMS)

Predictive mission Monitoring System (PEMS)

Out of the above, CEMS-Records emissions continuously over an extended and uninterrupted period of time as cited vide reference (1).The CEMS data provides the most accurate emission.
The system employed for monitoring is Non Extractive In-Situ System and stack sampler is used for measurement of NOx . Vide ref (7) the Colorimetrically using phenoldisulphonic acid (PDA) method employed is based on the Indian Standards : IS 11255 (Part 7) : 2005 Methods for measurement of Emission of Oxides of Nitrogen from Stationary sources.

\section{B. Principle of collection of sample}

The principle is to collect a grab sample in a dilute Sulphuric acid- hydrogen peroxide absorbing solution and the nitrogen oxides, except nitrous oxides are measured colorimetrically using the phenoldisulphonic acid.

The apparatus employed for collection of a grab of sample is done through a probe and analysed in the lab as shown below

\section{SAMPLING APPARATUS FOR NOX MEASUREMENT}

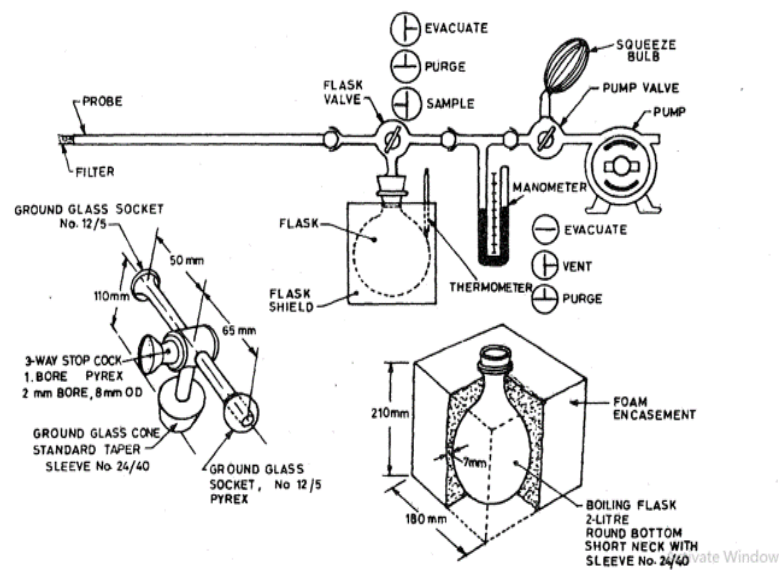

Fig 1. Sampling Train

\section{Data collected}

Samples were collected at the stack at two different pass and the NOx emitted in the flue gas is measured. The initial readings taken at the stack are as detailed below:

Table I

Initial readings of Nox emitted at stack

\begin{tabular}{|c|c|c|c|c|c|}
\hline \multirow{2}{*}{ PASS } & \multirow{2}{*}{$\begin{array}{c}\text { Sample } \\
\text { No. }\end{array}$} & \multirow{2}{*}{$\begin{array}{l}\text { Stack } \\
\text { Temp. } \\
\left({ }^{\circ} \mathbf{C}\right)\end{array}$} & \multirow{2}{*}{$\begin{array}{c}\text { Velocity } \\
(\mathbf{m} / \mathbf{s})\end{array}$} & \multicolumn{2}{|c|}{ Actual Values } \\
\hline & & & & $\begin{array}{c}\mathrm{NO2} \\
(\mathrm{mg} / \mathrm{Nm} 3)\end{array}$ & $\begin{array}{c}\text { Oxygen } \\
\text { as O2 } \\
(\%)\end{array}$ \\
\hline \multirow{2}{*}{ PASS A } & Sample I & 129 & 11.9 & 724 & 8.92 \\
\hline & Sample II & 130 & 12.5 & 912 & 9.21 \\
\hline \multirow{2}{*}{ PASS B } & $\begin{array}{c}\text { Sample } \\
\text { III }\end{array}$ & 127 & 13.2 & 895 & 10.70 \\
\hline & $\begin{array}{c}\text { Sample } \\
\text { IV }\end{array}$ & 131 & 13.7 & 785 & 10.32 \\
\hline
\end{tabular}

\section{Oxygen corrections}

All The results of $\mathrm{NO} 2$ has been compared with MoEF\&CC Emission Norms (2015) for Thermal Power Plants. It is observed that value of NO2 is exceeding the norms. The stack temperature is in the range of 127 to $131^{\circ} \mathrm{C}$ and the oxygen measured for the flue gas is in between 8.92 to 10.70 $\%$ as can be seen from the data 
presented in the Table above.

The excess air may be considered reason for dilution of flue gas and reducing the stack temperature $<135^{\circ} \mathrm{C}$. This low stack temperature causes condensation in exhaust duct line and stack. This may result into acid corrosion in flue gas path. There may be leakage from Air Pre Heater (APH) tubes, Electrostatic precipitator (ESP) - hopper bottom flange and multiple inspection window and fan inlet flange connection.

Hence Oxygen corrections are applied at $6 \% \mathrm{O} 2$ to the flue gas emissions for Sulphur Dioxide (SO2) from the measured $\mathrm{O} 2 \%$ by using CPCB Guidelines on Methodologies for Source Emission Monitoring, LATS/80/2013-2014. An amendment was issued vide GOI, MoEF \& CC Extraordinary Gazette dt. 29.06.2018. for O2 correction. The data of NO2 at measured $\mathrm{O} 2$ and calculated at $6 \% \mathrm{O} 2$.

Concentration values in $\mathrm{mg} / \mathrm{Nm} 3=$ Actual Concentration in $\mathrm{mg} / \mathrm{Nm} 3 \mathrm{x}[(21-\mathrm{Os}) /(21-\mathrm{Om})]$

(Corrected Values with 6\% O2),

Where,

Os = standard oxygen concentration $(6 \%)$

$\mathrm{Om}=$ measured oxygen concentration

\section{E. Readings after oxygen corrections}

Table II

Calculated Readings after oxygen correction

\begin{tabular}{|c|c|c|c|c|}
\hline \multirow{2}{*}{ PASS } & Sample No. & $\begin{array}{c}\text { Stack } \\
\text { Temp. } \\
\left({ }^{\circ} \mathbf{C}\right)\end{array}$ & $\begin{array}{c}\text { Velocity } \\
(\mathbf{m} / \mathbf{s})\end{array}$ & $\begin{array}{l}\text { Corrected Values } \\
\text { with 6\% O2 }\end{array}$ \\
\cline { 5 - 6 } & & & & NO2 $(\mathbf{m g} / \mathbf{N m 3})$ \\
\hline \multirow{2}{*}{ PASS A } & Sample I & 129 & 11.9 & 899 \\
\cline { 5 - 6 } & Sample II & 130 & 12.5 & 1160 \\
\hline \multirow{2}{*}{ PASS B B } & Sample III & 127 & 13.2 & 1303 \\
\cline { 5 - 6 } & Sample IV & 131 & 13.7 & 1103 \\
\hline
\end{tabular}

\section{F. Analysis of NOx emitted}

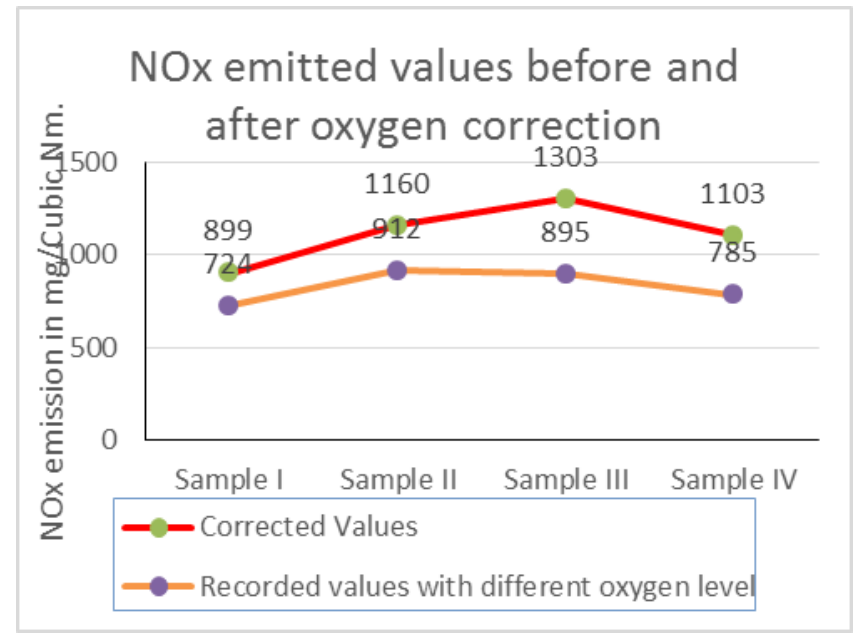

Fig. 2. Analysis of NOx Emitted

PRIMARY CONTROL MEASURE

( In flame Combustion Control) -

Dr.Malgorzata etal. vide ref.(5) stated that to reduce the NOx produced in the primary combustion zone and to reduce to nitrogen, in flame combustion control has to be used. For this it makes use of various techniques such as
- Low NOx Burner (LNB)

- Over Fire Air (OFA)

- Burners Out Of Service (BOOS)

- Flue gas recirculation (FGR)

SECONDARY CONTROL MEASURE - chemically reduces the NOx (i.e., reversal of oxidization) and remove oxygen from nitrogen oxides already present in the flue gas to molecular nitrogen through any of the following methods :

- Selective Catalytic Reduction (SCR)

- Selective Non Catalytic Reduction

(SNCR)

- Dry Sorption

\section{SELECTION OF OPTIMUM MEASURES}

Various control measures are analysed and the optimum control measure is selected for implementing the same to achieve the NOx emission reduction within the permissible norms.

Managing the catalyst in SCR system is a serious concern that merits stringent storage and disposal regulations and close oversight by the PCBs. Majority of coal in India is of poor quality and thermal power industry has raised concerns about the suitability of SCR for NOx control in Indian context. Independent experts believe that SCR technology will work for Indian coal, however, the erosive ash components such as silica and alumina will have an impact on the SCR and its catalyst causing a faster deactivation of the catalyst.

\section{IMPLEMENTATION OF CONTROL MEASURE}

According to several technology suppliers, the latest third generation LNB + OFA technology is capable of reducing NOx emissions well below the $300 \mathrm{mg} / \mathrm{Nm} 3$ limit. Power stations across the country have now begun the process for Implementation of primary control technologies. Further, this the primary combustion modification can be easily achieved within a short downtime of the existing plant, and the installation cost is also very less when compared with other control measures.

\section{LOW NOX BURNER (LNB)}

Boiler burners are the central element of effective combustion system design which includes fuel preparation, air fuel distribution, furnace design and combustion control. A burner supplies required amount of fuel and air and creates a condition of rapid mixing and produce flame. The mixing of air and fuel directly affects the flame stability, shape and emission.

\section{A. FORMATION OF NOX IN LOW NOX BURNER}

The formation of NO is influenced by the concentration of oxygen (which depends on the excess air) in the system, the flame temperature, the combustion conditions and nitrogen content in coal. Combustion of coal converts the nitrogen bound in coal to form products

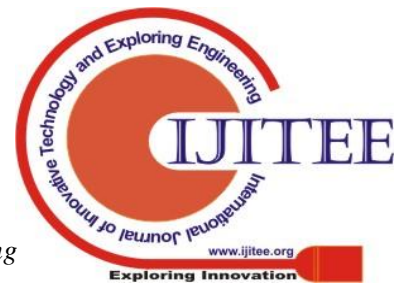


such as nitric oxide (NO), nitrogen dioxide (NO2) and nitrous oxide (N2O).

These products are collectively called oxides of nitrogen (NOx) - a major pollutant. In general, 90-95\% of NOx emitted from coal power plants is in the form of NO. In all combustion there are three opportunities for NOx formation. They are:

1. Fuel NOx - Fuel NOx is formed by the reaction of nitrogen in the fuel with oxygen in the combustion air. Fuels that contain nitrogen (e.g., coal) create "fuel NOx" that results from oxidation of the already-ionized nitrogen contained in the fuel. Fuel NOx contributes about 70- 80 per cent of the total NOx formed when coal combustion occurs in boiler at typical temperature ranges.

$$
\mathrm{O}+\mathrm{N} 2=\mathrm{NO}+\mathrm{N}
$$

2. Thermal NOx - Thermal NOx is formed when nitrogen and oxygen in the combustion air combine with one another at the high temperatures in a flame. Thermal NOx makes up the majority of NOx formed during the combustion of gases and light oils. The concentration of "thermal NOx" is controlled by the nitrogen and oxygen molar concentrations and the temperature of combustion. Thermal NOx generally accounts for about 5-25 per cent of the NOx formed during coal combustion.

\section{FLAME STRUCTURE}
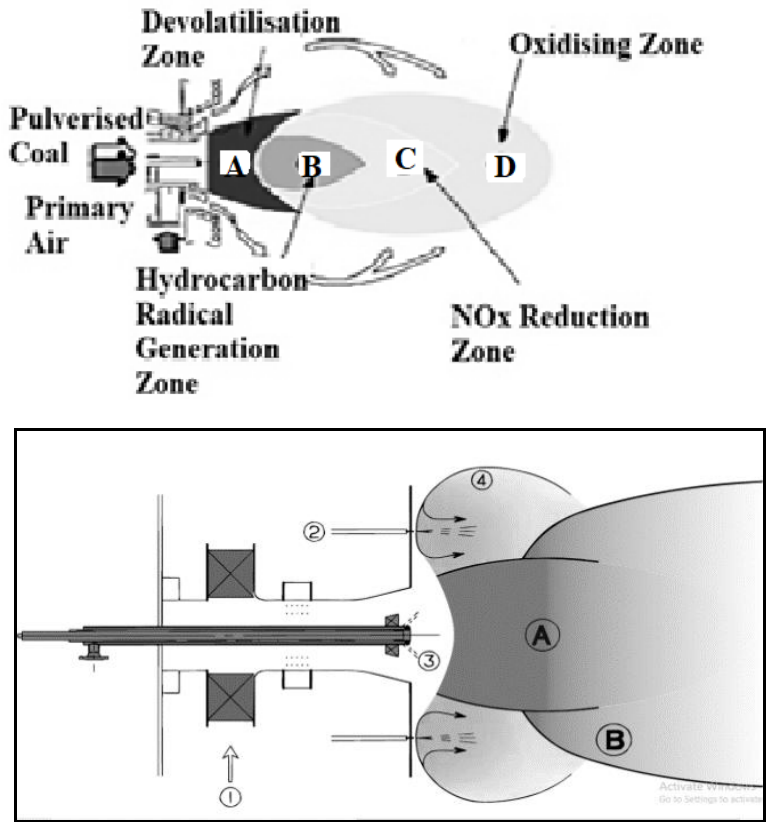

\section{B. TECHNIQUE OF LOW NOx BURNER}

The underlying technique involved in the technique of Low Nox Burner is that it combines two stages namely Split up of flame and Air staging

\section{OVER FIRE AIR (OFA)}

All burner rows in the boiler operate with a lack of oxygen. The combustion air is partly $(5-20 \%)$ injected through separate ports located above the top burner row in the boiler.

The principle underlying the Over Fire Air is that about 70-90 per cent of the required total combustion air provided near the burners create an oxygen-deficient, fuel-rich zone, leading to partial combustion of fuel. The balance of the combustion air is then injected above the burner elevation, through the OFA nozzles into the furnace, where combustion is completed.

- Divert typically diverts $20-30 \%$ of the combustion air from the burners to the upper furnace to stage the combustion process beyond what can be achieved with low-NOx burners i.e a portion of the combustion air away from the primary combustion zone minimizing the formation of fuel NOx.

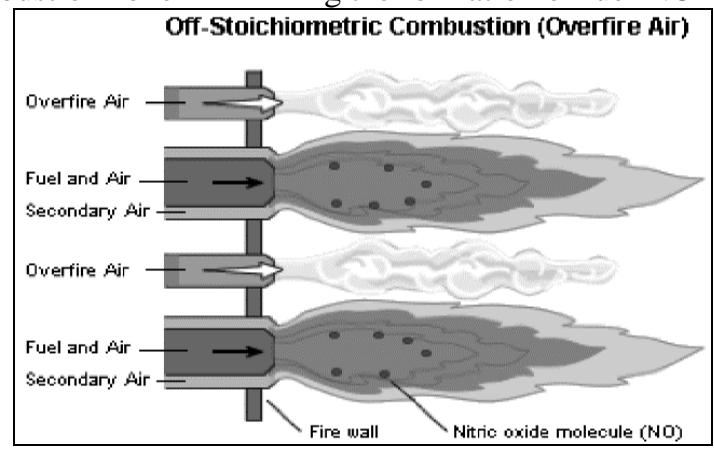

Fig. 6 Over Fire Air

- Unique ports are designed to inject air at the proper velocity and direction to complete combustion prior to the furnace exit at all boiler loads thereby ensuring advantageous air and fuel mixing.

- Balance of the combustion air is then injected above the burner elevation, through the OFA nozzles into the furnace, where combustion is completed

- OFA system can minimize NOx, achieving 30-40\% reductions beyond Low NOx burners.

- If required to improve burnout, tilting (vertical) and yawing (horizontal) port designs are available. NOx reductions achieved with an OFA system range from $25-40 \%$ depending on the fuel and initial NOx level.

- OFA is operational with most fuels and most types of boilers.

\section{COMBINATION OF LNB AND OFA}

1) To achieve optimum NOx reduction at a given load on a particular fuel LNB + OFA systems should be used together in-combination. However, the unit's NOx performance decreases whenever a variable changes (units operating profile, load, fuel quality, etc.).

2) To assist in the maintenance of NOx performance, combustion optimization systems which monitor key combustion parameters - NOx, O2, CO, unburnt carbon and boiler efficiency-should be integrated into the boiler control systems. All these measurements, if performed accurately, can be used to control both excess

3) air and coal flow to the individual burners resulting in optimized combustion conditions. 


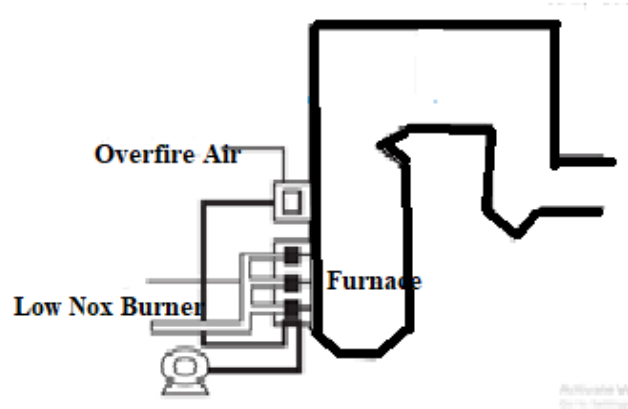

Fig.7 Line Diagram of position of low NOx Burner and OFA

LNB and OFA combustion perform as follows:

Low Nox Burners: Precisely control combustion to

Over Fire air: Completes the combustion

Together LNB + OFA can reduce upto $50-75 \%$ NOx.

\section{FINAL READINGS AFTER MODIFICATION OF BURNER}

The optimum control measure to reduce NOx emission was carried out by implementing the methodology of In combustion control measure wherein the conventional burner was modified with the Low NOx Burner together with Over Fire Air port in the Boiler.

Table 3

Final readings of Nox emitted at stack

\begin{tabular}{|c|c|c|c|c|c|}
\hline \multirow{2}{*}{ PASS } & \multirow{2}{*}{$\begin{array}{c}\text { Sample } \\
\text { No. }\end{array}$} & \multirow{2}{*}{$\begin{array}{l}\text { Stack } \\
\text { Temp. } \\
\left({ }^{\circ} \mathbf{C}\right)\end{array}$} & \multirow{2}{*}{$\begin{array}{c}\text { Velocity } \\
(\mathbf{m} / \mathbf{s})\end{array}$} & \multicolumn{2}{|c|}{ Actual Values } \\
\hline & & & & $\begin{array}{c}\mathrm{NO2} \\
(\mathrm{mg} / \mathrm{Nm} 3)\end{array}$ & $\begin{array}{c}\text { Oxygen } \\
\text { as } 02 \\
(\%)\end{array}$ \\
\hline \multirow{2}{*}{ PASS A } & Sample I & 129 & 11.9 & 170 & 8.92 \\
\hline & Sample II & 130 & 12.5 & 186 & 10.26 \\
\hline \multirow{2}{*}{ PASS B } & $\begin{array}{c}\text { Sample } \\
\text { III }\end{array}$ & 127 & 13.2 & 175 & 10.50 \\
\hline & $\begin{array}{c}\text { Sample } \\
\text { IV }\end{array}$ & 131 & 13.7 & 183 & 9.82 \\
\hline
\end{tabular}

\section{A. FINAL VALUES AFTER OXYGEN CORRECTION}

Oxygen corrections are applied at $6 \% \mathrm{O}_{2}$ to the flue gas emissions for Nitrogen Dioxide $\left(\mathrm{NO}_{2}\right)$ from the measured $\mathrm{O}_{2} \%$ by using CPCB Guidelines on Methodologies for Source Emission Monitoring, LATS/80/2013-2014.

Table 4

Final Measurement of NOx after oxygen correction

\begin{tabular}{|c|c|c|c|c|}
\hline PASS & Sample No. & $\begin{array}{c}\text { Stack } \\
\text { Temp. } \\
\left({ }^{\circ} \mathbf{C}\right)\end{array}$ & $\begin{array}{c}\text { Velocity } \\
(\mathrm{m} / \mathrm{s})\end{array}$ & $\begin{array}{c}\text { Corrected } \\
\text { Values with } \\
\mathbf{6 \%} \text { O2 }\end{array}$ \\
\cline { 5 - 6 } & & $\begin{array}{c}\text { NO2 } \\
(\mathrm{mg} / \mathrm{Nm3})\end{array}$ \\
\hline $\begin{array}{c}\text { PASS } \\
\text { A }\end{array}$ & Sample I & 129 & 11.9 & 211 \\
\cline { 2 - 5 } & Sample II & 130 & 12.5 & 260 \\
\hline
\end{tabular}
reduce NOx.

\begin{tabular}{|c|c|c|c|c|}
\hline $\begin{array}{c}\text { PASS } \\
\text { B }\end{array}$ & Sample III & 127 & 13.2 & 250 \\
\cline { 2 - 5 } & Sample IV & 131 & 13.7 & 246 \\
\hline
\end{tabular}

\section{A. ANALYSIS OF NOx EMITTED FROM STACK AFTER MODIFICATION}

From the above tables it could be seen that after modifying the burner, the exact value of NOx emitted in the flue gas from the stack is well within the permissible limits of $300 \mathrm{mg} /$ Cubic Nm.(as prescribed by MOEF\& CC)

Table 5 NOx Reduction Efficiency

\begin{tabular}{|l|c|c|c|c|}
\hline PAS & SAMPLE & $\begin{array}{c}\text { NOx } \\
\text { Emission } \\
\text { before } \\
\text { modifying( } \\
\text { mg/Cubic } \\
\text { Nm) }\end{array}$ & $\begin{array}{c}\text { NOx } \\
\text { Emission } \\
\text { after } \\
\text { modifying } \\
\text { (mg/Cubic } \\
\text { Nm) }\end{array}$ & $\begin{array}{c}\text { NOx } \\
\text { Redu } \\
\text { ction } \\
\text { Effici } \\
\text { ency } \\
(\%)\end{array}$ \\
\hline $\begin{array}{l}\text { PAS } \\
\text { S A }\end{array}$ & Sample 1 & $\mathbf{8 9 9}$ & $\mathbf{2 1 1}$ & $\mathbf{7 6}$ \\
\cline { 2 - 5 } & Sample 2 & $\mathbf{1 1 6 0}$ & $\mathbf{2 5 9}$ & $\mathbf{7 8}$ \\
\hline PAS & Sample 3 & $\mathbf{1 3 0 3}$ & $\mathbf{2 5 0}$ & $\mathbf{8 0}$ \\
\cline { 2 - 5 } S B & Sample 4 & $\mathbf{1 1 0 3}$ & $\mathbf{2 4 6}$ & $\mathbf{7 8}$ \\
\hline
\end{tabular}

From the above table it could be seen clearly that there is an abrupt reduction in the emission of NOx. The above modifying of burners has been carried out in the existing thermal power plants so as to comply with the latest norms within the minimum downtime without affecting the power generation with a minimum investment. The installation of the Low Nox Burners and over fire air port does not warrant any modification in ducts and easy to install the Low NOx Burner by replacing the boiler burner.

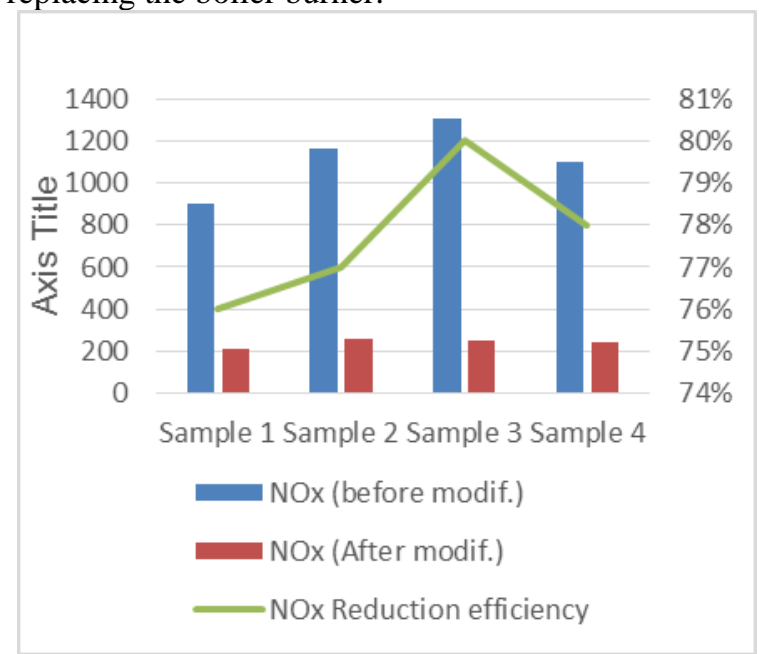

Fig 8. NOx Emission Reduction Chart As stated earlier, the emission of NOx has reduced drastically to less than $300 \mathrm{mg} / \mathrm{cubic} \mathrm{Nm}$ ( norms fixed by MOEF \&CC) after modification and the efficiency achieved is around $78 \%$.

\section{CONCLUSION}

After modifying the burner in the existing thermal power station with Low Nox Burner and Over Fire Air Port, the emission of NOx in coal fired thermal power station has considerably reduced. 
Advantages of Using LNB with OFA:

When compared with other in Flame combustion control measures, this LNB with OFA has been successfully carried out due to following aspects :

- Simplified conceptual design and ease of construction

- Minimum downtime for installation

- Minimal or no changes to existing air piping, fuel piping and control systems

- Minimal installation effort as no addl. space nor auxiliary equipment/systems are required.

- Short implementation period

- Operation control:

- Sophisticated automation control

- Reliable \& safe operation

- Reduction in overall flame diameter due to supplemental high impact air jets.

- Reduction of the total air through the combustion head minimises the availability of free oxygen to combine with fuel nitrogen and increases the sub-stochiometric air.

- Nox Emission efficiency reduced to $80 \%$

- Maintenance control:

- Maintenance-free performance with no moving parts, chemical additives or auxiliary systems.

- No by-products for disposal

- Able to perform with various types of fuel with different coal characteristics.

- Fuel savings of $10 \%$ or more is achieved.

- Noise reduction of $3 \mathrm{~dB}$ or more is achieved

- Cost Involved:

- Investment costs works out to around 8-10 lakhs/MW

- Based on fuel savings, the Project

investment payback is aimed within 12 -

24 months.

LNB with OFA combustion process is improved to obtain maximum benefits for decreasing the temperature maximum.

\section{DISADVANTAGES:}

- LNBs Leads to an increased level of unburnt carbon and emissions of carbon monoxide (CO). However, better design and operations can keep the levels of unburnt carbon and $\mathrm{CO}$ to a minimum.

For the existing plants the in combustion control measure alone could be considered since the changes to be adopted in modifying the burner does not affect the generation for a long period and modifying can be carried out effectively and economically.

Considering the advantages and other aspects, it is seen that the LNB combined along with Over Fire Air technology is one of the least expensive options of reducing NOx emissions from the boiler and can be easily installed in the existing boilers without affecting the power generation within minimum period without any modification in ducts and with minimum expenditure. However for the new thermal power stations installed after the year 2017, along with LNB other post combustion treatment of Selective Catalytic Reduction has to be installed since the reduction in NOx emission has been fixed as $100 \mathrm{mg} / \mathrm{Cubic} \mathrm{Nm}$, wherein the reduction efficiency works out to $94 \%$..

\section{REFERENCES}

1. Andreea Voina, Brandusa Pantelimon, Georgeta Aleca, Incd Ecoind International Symposium-Simi 2011 "The Environment And The Industry" Methods for measurement, monitoring and control of NOX emissions

2. Besire Cena*, Mehush Aliu, Tahir Musliu during the year 2010 in the Journal of Environmental Application and Science published a paper on "Measurements of Emission of Gases SO2, NOx, CO and CO2 from the Burning Process in the Furnaces of Power Plant "Kosova B" vide Vol. 5 (2): 172-174 (2010)

3. Chandra H, Paliwal S, and Tripathi A, “ Mitigation Of Emission In Thermal Power Plant Using Conventional And Non-Conventiona Fuel", International Journal of Engineering Science Invention Vol 2 issue 4 Apr 2013 pp 01-06.

4. Dongmei Li, Yang Guo, Yuan Li, Pengguo Ding, Qiang Wang, Zhenqian Cao, " Air Pollutant Emissions From Coal-Fired Power Plants", Haepc electric power research institute, zhengzhou, china Published in the Open journal of Air Pollution (2012,1,37-41)

5. Dr Malgorzata Wiatros-Motyka 'NOx control for high-ash coal-fired power plants in India . Clean Energy, Volume 3, Issue 1, 27 February 2019, Pages 24-33,

6. Eng. Florentina CĂLUGĂRU, Conf. PhD. eng. “ Installation of Low Nox Burners at 100 MW units of Bucharest south thermal power plant" in his paper published in Termotehnica 2/2012

7. Guidelines of Continuous Emission Monitoring System issued by Central Polution Control Board during the year July 2017.

8. James E. Staudt, Ph.D. "Control Technologies To Reduce Conventional And Hazardous Air Pollutants From Coal-Fired Power Plants", Andover technology partners, Prepared for NorthEast states for coordinated air use management (2011)

9. John H. Margeson, William J. Mitchell, Jack C. Suggs \& M. Rodney, "Integrated Sampling And Analysis Methods For Determining NOx Emissions At Electric Utility Plants", Journal of the Air Pollution Control Association, 32:12,1210-1215 published on Mar 2012 Midgett

10. Kenichi Ochi, Kenji Kiyama,Hidehisa Yoshizako, Dr. Eng.,Hirofumi Okazaki, Masayuki Taniguchi, Dr. Eng. " Latest Low-NOx Combustion Technology for Pulverized-coal-fired Boilers “, Published in Hitachi Review Vol 58 (2009), No.5.

11. Kishore B Porate, Krishna L.Thakre, Gana Shyam L. Bodhe, "Minimization Of GHG In Coal Based Thermal Power Plant", Published in the Journal of Electrical Engineering.

12. 12.Levaggi. D.A ,Zerrudo.R, Karels.G, Oyung.W \& Feldstein.M (2012) "An

13. Integrated Manual Impinger Method for The Simultaneous Determination of NOx and Sox in Source Effluents, Journal of the Air Pollution Control Association, 26:8, 783-786 Published during March 2012.

14. Li.J and Li.W.W, "Control Technology Research on Low-NOx Combustion System in Large-Scale Coal-Fired Power Plants", Advanced Materials Research, Vols. 953-954, pp. 730-733, 2014

15. Ministry of Environment and Forest -Guidelines for the measurement of Ambient Air Pollutant- Guidelines for Manual Sampling and Analyses- Issued by Central Pollution Control Board.

16. Marc Karell and Amit Chattopadhyay (2000) -“ NOx Emission Reduction Strategies in the Journal Pollution Online 
17. Moo Been Chang, How Ming Lee, Feeling Wu \& Chi Ren Lai (2004) "Simultaneous Removal of Nitrogen Oxide/Nitrogen Dioxide/Sulfur Dioxide from Gas Streams by Combined Plasma Scrubbing Technology, Journal of the Air \& Waste Management Association, 54:8, 941-949,

18. Moti L. Mittal, Chhemendra Sharma and Richa Singh "Estimates of Emissions from Coal Fired Thermal Power Plants in India "Council of Scientific and Industrial research during the year 2010

19. Nihalani S.A, Mishra Y, Juremalani J, "Emission Control Technologies For Thermal Power Plants IOP conference series : Material Science and Engineering (2018), Gujarat, India

20. Ravi K. Srivastava , Robert E. Hall, Sikander Khan, Kevin Culligan \& Bruce W. Lani 2012 in the Journal of the Air \& Waste Management Association published "Nitrogen Oxides Emission Control Options for Coal-Fired Electric Utility Boilers”, vide Vol , 55:9, 1367-1388

21. Satyashree Godka, Rohit Kumar, Navneet Singh, Himani Khandelwa, "Estimation Of GHG Emission From Indian Coal Based Thermal Power Plant", Published in IOSR journal of Engineering Apr 2012, Vol.2(4) pp: 591-597

22. 21.Shahzadbaig K, Yousuf M, "Coal Fired Power Plants: Emission Problem And Controlling Techniques", Published in the Journal of Earth Science and Climatic Change (2017), Ryerson university, Toronto, Canada,.

23. Sujatha K, Bhavani P.G, Godavari T, Ponmagal R.S, and Su-Qun Cao. "Smart Sensor For NOx and SO2 Emissions In Power Station Boilers", Published in the Indian Journal of Science and Technology, Vol 8 (27) Oct 2015

24. Sunil P.Agarwal " in his paper on "Practical approach to SOx and NOx Measurement

25. Yuan Ji Pei, Ge Li, Xiang Qi Wang, Yun Wu Zhang, Guang Yao Feng, Yong Wang, Wei Wei, Yili Hong, Shaojun Fu, Hui Gao, Yu Xiong Li, Hong Jun Zhou, Yang Cao Tian, Lei Shang, Xiao Li Dong, Sai Dong, Liu Si Sheng," A Low cost and high efficient facility for removal of SO2 and NOx in the flue gas from Coal Fire Power Plant "in his proceedings on the Particle Accelerator change held at Chicago during the year 2001

\section{AUTHORS PROFILE}

\section{T.P.Meikandaan,Associate}

Department of Civil Engineering, Bharath Institute of Higher Education and Research, Selaiyur, Chennai, Tamilnadu

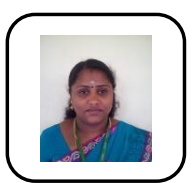

M. Hemapriya, Assistant Professor,Department of Civil Engineering, Bharath Institute of Higher Education and Research, Selaiyur, Chennai, Tamilnadu

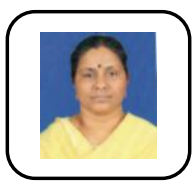

V. Vidhya, PG Student,Department of Civil Engineering, Bharath Institute of Higher Education and Research, Selaiyur, Chennai, Tamilnadu 